\title{
MODEL TARIKAN PERJALANAN MINIMARKET DI BEKASI
}

\author{
Budiharso Hidayat, A.TD, MT \\ Dosen STTD \\ Jl. Raya Setu Km. 3,5 Cibuntu, \\ Cibitung, Bekasi 17520 \\ Telp./fax. 0218254640 \\ info.p3m.sttd@gmail.com \\ aim.harso@gmail.com
}

\author{
Drs. Eko Sudriyanto, MM \\ Dosen STTD \\ Jl. Raya Setu Km. 3,5 Cibuntu, \\ Cibitung, Bekasi 17520 \\ Telp./fax. 0218254640
}

Fery Subekti, S.SiT., M.Sc

Dosen STTD

Jl. Raya Setu Km. 3,5 Cibuntu,

Cibitung, Bekasi 17520

Telp./fax. 0218254640

\author{
FX Bowo Priyambodo, S.SiT., M.Sc \\ Dosen STTD \\ Jl. Raya Setu Km. 3,5 Cibuntu, \\ Cibitung, Bekasi 17520 \\ Telp./fax. 0218254640
}

\begin{abstract}
Changes in land use for trading activities will be interesting journey in accordance with the characteristics of land use and land-use location. Added traveling affect traffic performance due to the increase in traffic volume on the roads around the mini operating. Restrictions on land use for trading activities are given wide limits of $1,000 \mathrm{~m}^{\wedge} 2$ for the mini unclear boundaries must be done andalalin having regard to the pull of the trip.

Especially restrictions used to predict the level of traction traveling if there are plans to build / development minimarket on a particular area.

Relations with the journey of building area, labor and traffic volume has been no research on it.
\end{abstract}

\begin{abstract}
ABSTRAK
Perubahan guna lahan untuk kegiatan perdagangan akan menarik perjalanan sesuai dengan karakteristik guna lahan dan lokasi penggunaan lahan. Pertambahan perjalanan mempengaruhi kinerja lalu lintas yang disebabkan pertambahan volume lalu lintas pada ruas jalan sekitar minimarket yang beroperasi.

Batasan pada guna lahan untuk kegiatan perdagangan diberikan batasan luas $1.000 \mathrm{~m}^{2}$ yang untuk minimarket belum jelas batasan harus dilakukan andalalin dengan memperhatikan besarnya tarikan perjalanan.

Terutama batasan yang digunakan untuk memprediksi tingkat tarikan perjalanan apabila ada rencana pembangunan/pengembangan minimarket pada suatu daerah tertentu.

Hubungan perjalanan dengan luas bangunan, tenaga kerja dan volume lalulintas belum ada penelitian terhadap hal ini.
\end{abstract}




\section{LATAR BELAKANG}

Menurut Wahyunto dalam Rina Widayanti, 2010 menyatakan bahwa perubahan tata guna lahan adalah bertambahnya suatu penggunaan lahan dari satu sisi penggunaan ke penggunaan yang lainnya diikuti dengan berkurangnya tipe tata guna lahan yang lain dari suatu waktu ke waktu berikutnya.

Pertumbuhan peningkatan intensitas lahan akan mengakibatkan peningkatan terhadap bangkitan dan tarikan pergerakan dari dan ke lahan tersebut, yang berarti bahwa pergerakan arus lalu lintas yang dihasilkan semakin meningkat.

Standar yang ada untuk guna lahan pertokoan dengan Gross Flor Area (GFA) melebihi $1000 \mathrm{~m} 2$ wajib dilaksanakan analisis dampak lalu lintas, tapi pada kenyataan luasan minimarket kurang dari itu, dan jumlah tarikan perjalanan cukup besar. Sehingga untuk minimarket belum ada kejelasan apakah harus wajib ANDALL

tujuan penelitian

1. Mengetahui karakteristik minimarket di Bekasi

2. Mengetahui fluktuasi lalu lintas di Sekitar Minimarket

3. Mengetahui tarikan perjalanan Minimarket

4. Menilai hubungan antara tarikan perjalanan, luas bangunan, jumlah tenaga kerja dan jenis pelayanan berdasarkan lokasi

5. Membandingkan tarikan perjalanan dengan volume lalu lintas.

\section{MANFAAT PENELITIAN}

Hasil penelitian ini dapat digunakan untuk mengetahui tingkat tarikan perjalanan minimarket dan pengaruhnya terhadap lalu lintas sekitar yang berguna sebagai alat bantu peramalan tarikan perjalanan dalam mengevaluasi rancana pembangunan/pengembangan minimarket.

\section{LANDASAN TEORITIK}

1. Karakteristik Minimarket

2. Tarikan Perjalanan $\rightarrow$ Trip generation, Four Strep Model 
3. Hubungan antara Tarikan Perjalanan, Luas Bangunan, Jumlah Tenaga Kerja dan Jenis Pelayanan berdasarkan Lokasi serta Volume Lalu Lintas. $\rightarrow$ Regresi, Uji Statistik

4. Tahap Penelitian :

$\checkmark$ Inventarisasi lokasi minimarket

$\checkmark$ Pemilihan sampel minimarket

$\checkmark$ Pengumpulan data lalu lintas terklasifikasi, jumlah pengunjung, wawancara pengunjung, inventaris karakteristik minimarket

$\checkmark$ Analisis data

$\checkmark$ perbandingan tarikan perjalanan dengan volume lalu lintas

\section{METODOLOGI PENELITIAN}

Desain/Rancangan Tindakan Penelitian

1. Implementasi Tindakan : Melakukan pengukuran, pengamatan dan observasi langsung pada lokasi minimarket yang telah ditetapkan.

2. Observasi dan Interprestasi : Observasi terhadap volume lalu lintas, jumlah pengunjung, karakteristik pengunjung dan karakteristik minimarket.

3. Analisis dan Refleksi : Hubungan antara tarikan perjalanan dengan karakteristik minimarket dan pengunjung serta volume lalu lintas di ruas jalan sekitar minimarket dan diwujudkan dalam bentuk hubungan antara tarikan perjalanan, volume lalu lintas, luas bangunan, jumlah tenaga kerja dan jenis pelayanan berdasarkan lokasi.

4. Siklus Tindakan : Umpan balik hasil analisis dengan kebutuhan yang sesuai dengan standard teknis.

\section{TEKNIK PENGUMPULAN DATA}

1. Pengenalan kondisi lokasi penelitian

2. Pengamatan, pengukuran dan penghitungan lalu lintas jalan dan jumlah pengunjung, inventarisasi karakteristik minimarket, wawancara karakteristik pengunjung minimarket. 


\section{TEKNIK ANALISIS DATA}

Dengan Pendekatan :

1. Volume lalu lintas terklasifikasi

2. Tingkat tarikan perjalanan

3. Hubungan antara taikan perjalanan dengan volume lalu lintas, luas bangunan, jumlah tenaga kerja dan jenis pelayanan berdasarkan lokasi

\section{ANALISA \& PEMBAHASAN}

1. Survai Inventarisasi Ruas Jalan

Objek penelitian yang dibutuhkan dalam penelitian ini memiliki kriteria antara lain :

a. Disesuaikan dengan status jalan yang ada di Kabupaten Bekasi antara lain:

- Jalan Nasional adalah ruas jalan Jalan Teuku Umar;

- Jalan Propinsi adalah Jalan Raya Setu; Jalan Kalimalang;

- Jalan Kabupaten adalah Jalan Raya Cikarang Cibarusah;

b. Karakteristik luasan;

c. Karakteristik pelayanan;

d. Karakteristik tata guna lahan;

karakteristik lokasi studi

\begin{tabular}{|c|c|c|c|c|c|}
\hline No & Minimarket & Lokasi & Ruas Jalan & Status Jalan & $\begin{array}{l}\text { Komposisi Tata } \\
\text { Guna Lahan }\end{array}$ \\
\hline 1 & Indomart & Dekat Perumahan GMM & Jalan Raya Setu & Propinsi & Perumahan \\
\hline 2 & Indomart & Dekat Perumahan PKB & Jalan Raya Setu & Propinsi & \multirow{2}{*}{ Perumahan } \\
\hline & & & & & \\
\hline 3 & Indomart & Dekat Persimpangan Kalimalang & Jalan Raya Setu & Propinsi & \multirow{2}{*}{$\begin{array}{c}\text { Perumahan, } \\
\text { Pertokoan }\end{array}$} \\
\hline & & & & & \\
\hline 4 & Alfamart & Dekat Persimpangan Kobra & Jalan Raya Kalimalang & Propinsi & \multirow{2}{*}{$\begin{array}{c}\text { Pertokoan, } \\
\text { Perumahan, Hotel }\end{array}$} \\
\hline & & & & & \\
\hline 5 & Alfamart & Dekat Persimpangan Cibitung & Jalan Teuku Umar & Nasional & \multirow{2}{*}{$\begin{array}{c}\text { Industri, Pertokoan, } \\
\text { Perkantoran }\end{array}$} \\
\hline & & & & & \\
\hline 6 & Alfamart & Dekat Persimpangan Kampung Utan & Jalan Teuku Umar & Nasional & \multirow{2}{*}{$\begin{array}{l}\text { Pertokoan, } \\
\text { Perumahan, }\end{array}$} \\
\hline & & & & & \\
\hline 7 & Alfamart & Dekat Akses Tol Cikarang Barat & Jalan Raya Cikarang -- Cibarusah & Kabupaten & \multirow{2}{*}{$\begin{array}{l}\text { Pertokoan, } \\
\text { Perkantoran }\end{array}$} \\
\hline & & & & & \\
\hline 8 & Indomart & Dekat Persimpangan Lippo Cikarang & Jalan Raya Cikarang -- Cibarusah & Kabupaten & \multirow{2}{*}{$\begin{array}{l}\text { Pertokoan, } \\
\text { Perumahan }\end{array}$} \\
\hline & & & & & \\
\hline 9 & Alfamart & Dekat Pasar Modern Alamanda & Jalan Raya Karang Satria & Kabupaten & \multirow{2}{*}{$\begin{array}{c}\text { Perumahan, } \\
\text { Pertokoan }\end{array}$} \\
\hline & & & & & \\
\hline 10 & Indomart & Dekat Persimpangan Pilar & Jalan Ki Hajar Dewantara & Kabupaten & Perumahan \\
\hline
\end{tabular}

\begin{tabular}{|c|c|c|c|c|c|c|}
\hline \multirow{3}{*}{ No } & \multirow{3}{*}{ Minimarket } & \multirow{3}{*}{ Lokasi } & \multicolumn{4}{|c|}{ Karakteristik Pelayanan } \\
\hline & & & Belanja & Bermain & ATM & Lain -- Lain \\
\hline & & & $(\%)$ & $(\%)$ & $(\%)$ & $(\%)$ \\
\hline 1 & Indomart & Dekat Perumahan GMM & $\mathrm{v}$ & $\mathrm{v}$ & $\mathrm{v}$ & $\mathrm{v}$ \\
\hline 2 & Indomart & Dekat Perumahan PKB & $\mathrm{V}$ & $\mathrm{x}$ & $\mathrm{V}$ & $\mathrm{V}$ \\
\hline 3 & Indomart & Dekat Persimpangan Kalimalang & $\mathrm{V}$ & $\mathrm{x}$ & $\mathrm{V}$ & $\mathrm{V}$ \\
\hline 4 & Alfamart & Dekat Persimpangan Kobra & $\mathrm{V}$ & $\mathrm{x}$ & $\mathrm{V}$ & $\mathrm{x}$ \\
\hline 5 & Alfamart & Dekat Persimpangan Cibitung & $\mathrm{V}$ & $\mathrm{x}$ & $\mathrm{V}$ & $\mathrm{V}$ \\
\hline 6 & Alfamart & Dekat Persimpangan Kampung Utan & $\mathrm{V}$ & $\mathrm{x}$ & $\mathrm{x}$ & $\mathrm{V}$ \\
\hline 7 & Alfamart & Dekat Akses Tol Cikarang Barat & $\mathrm{V}$ & $\mathrm{V}$ & $\mathrm{V}$ & $\mathrm{x}$ \\
\hline 8 & Indomart & Dekat Persimpangan Lippo Cikarang & $\mathrm{V}$ & $\mathrm{V}$ & $\mathrm{x}$ & $\mathrm{x}$ \\
\hline 9 & Alfamart & Dekat Pasar Modern Alamanda & $\mathrm{V}$ & $\mathrm{V}$ & $\mathrm{x}$ & $\mathrm{V}$ \\
\hline 10 & Indomart & Dekat Persimpangan Pilar & $\mathrm{V}$ & $\mathrm{V}$ & $\mathrm{V}$ & $\mathrm{x}$ \\
\hline
\end{tabular}




\section{HASIL SURVAI TARIKAN PERJALANAN}

Survai tarikan dilakukan pada beberapa lokasi minimarket yang telah ditentukan berdasarkan kriteria - kriteria diatas.

1 Indomart Jalan Raya Setu (Dekat Perumahan Graha Mustika Media)

Berdasarkan grafik fluktuasi tarikan perjalanan indomart diatas diketahui bahwa tarikan perjalanan terbanyak adalah sepeda motor dengan jumlah kendaraan sebanyak 45 kendaraan pada pukul 18.30 - 19.30 WIB. Banyaknya tingkat tarikan perjalanan pada minimarket ini disebabkan pelayanan yang ada tidak hanya swalayan tetapi juga terdapat pelayanan lain seperti ATM, tempat bermain anak, toko baju, dan lain - lain, hal ini tentunya dapat menambah minat pengunjung untuk datang ke lokasi minimarket ini.

2 Alfamart Jalan Raya Setu (Dekat Perumahan Balai PKB)

Grafik fluktuasi tarikan perjalanan alfamart diatas menunjukkan bahwa tarikan perjalanan terbanyak pada alfamart Jalan Raya Setu (Dekat Perumahan Balai PKB) adalah sepeda motor dengan jumlah tarikan perjalanan sebanyak 23 kendaraan pada pukul 16.45 - 17.45 WIB, untuk pejalan kaki sebanyak 15 orang pada pukul 18.45 19.45 WIB. Pada lokasi alfamart ini juga terdapat pelayanan laiinya seperti ATM dan permainan anak, sehingga dapat membantu dalam menarik minat pengunjung minimarket.

3 Alfamart Jalan Raya Setu (Dekat Persimpangan Kalimalang - Jalan Raya Setu)

Grafik fluktuasi tarikan perjalanan minimarket diatas menunjukkan bahwa tarkan perjalanan tertinggi adalah sepeda motor dengan tingkat tarikan perjalanan sebanyak 44 kendaraan pada waktu 18.00 - 19.00 WIB. Pada lokasi minimarket ini juga terdapat ATM dan kerjasama usaha lainnya seperti pedagang martabak, jus dan lain - lain.

4 Alfamart Jalan Kalimalang (Dekat Persimpangan Kobra)

Lokasi alfamart diatas adalah pada Jalan Kalimalang dekat persimpangan Kobra, berdasarkan grafik diatas diketahui bahwa tarikan perjalanan terbanyak adalah sepeda motor dengan tingkat tarikan perjalanan sebanyak 27 kendaraan pada pukul 16.15 17.15 WIB.

5 Alfamart Jalan Teuku Umar (Dekat Persimpangan Kampung Utan)

Lokasi alfamart diatas adalah pada Jalan Teuku Umar (Dekat Persimpangan Kampung Utan), berdasarkan grafik diatas diketahui bahwa tarikan perjalanan terbanyak adalah sepeda motor dengan tingkat tarikan perjalanan sebanyak 22 kendaraan pada pukul 
16.45 - 17.45 WIB dan pengunjung dengan menggunakan mobil tertinggi pada pukul $16.15-17.15$ WIB.

6 Alfamart Jalan Teuku Umar (Dekat Persimpangan Cibitung)

Lokasi alfamart diatas adalah pada Jalan Teuku Umar (Dekat Persimpangan Cibitung), berdasarkan grafik diatas diketahui bahwa tarikan perjalanan terbanyak adalah sepeda motor dengan tingkat tarikan perjalanan sebanyak 33 kendaraan pada pukul 18.15 19.15 WIB.

7 Indomart Jalan Cikarang - Cibarusah (Dekat Akses Tol Cikarang Barat)

Lokasi Indomart Jalan Cikarang - Cibarusah (Dekat Akses Tol Cikarang Barat), berdasarkan grafik diatas diketahui bahwa tarikan perjalanan terbanyak adalah sepeda motor dengan tingkat tarikan perjalanan sebanyak 40 kendaraan pada pukul 17.15 18.15 WIB

8 Indomart Jalan Cikarang - Cibarusah (Dekat Lippo Cikarang)

Lokasi Indomart Jalan Cikarang - Cibarusah (Dekat Lippo Cikarang), berdasarkan grafik diatas diketahui bahwa tarikan perjalanan terbanyak adalah sepeda motor dengan tingkat tarikan perjalanan sebanyak 41 kendaraan pada pukul 17.15 - 18.15 WIB

\section{A HASIL SURVAI WAWANCARA PENGUNJUNG}

Lokasi Indomart jalan Raya Setu (Dekat Perumahan GMM) $63 \%$ Perjalanan menuju Indomart berasal dari Rumah atau tempat tinggal dan $37 \%$ merupakan perjalanan lintas.

Dan maksud perjalanan dari pengunjung $36.7 \%$ bermaksud untuk berbelanja, $30 \%$ pengunjung bertujuan untuk menuju fasilitas pengambilan uang (ATM) dan 23 $\%$ pengunjung bertujuan untuk menggunakan fasilitas hiburan (permainan)

Pada Lokasi Alfamart Jalan Kalimalang (Dekat Persimpangan Kobra) $30 \%$ Perjalanan menuju Indomart berasal dari Rumah atau tempat tinggal dan $70 \%$ merupakan perjalanan lintas. Maksud perjalanan dari pengunjung $76.7 \%$ bermaksud untuk berbelanja, $23.3 \%$ pengunjung bertujuan untuk menuju fasilitas pengambilan uang (ATM)

Pada Lokasi Alfamart Jalan Teuku Umar (Dekat Persimpangan Tol Cibitung) $53.3 \%$ Perjalanan menuju Alfamart berasal dari Rumah atau tempat tinggal dan $46.7 \%$ merupakan perjalanan lintas 
Dan maksud perjalanan dari pengunjung $63.3 \%$ bermaksud untuk berbelanja, $23.3 \%$ pengunjung bertujuan untuk menuju fasilitas pengambilan uang (ATM) Dan $13.3 \%$ untuk keperluan lainnya

\section{ANALISA KORELASI}

Data yang datang dari surveyor kemudian dilakukan rekapitulasi ke dalam computer dengan bantuan perangkat lunak. Variabel data yang dikumpulkan dari wawancara asal tujuan pada bangunan tarikan perjalanan.

Untuk kepentingan dalam pembangunan model, maka data yang dikumpulkan diolah menjadi variabel sebagai berikut:

1. Jumlah Kasir

2. Jumlah Layanan

3. Jenis Guna lahan

Sedangkan untuk kepentingan besaran dan arah pergerakan perjalanan, variabel data yang dikumpulkan adalah:

1. Jumlah penghuni dan pengunjung bangunan tarikan.

2. Asal perjalanan.

Setelah data diolah ke dalam komputer untuk memudahkan proses analisa. Tahapan analisis yang dilakukan sebagai berikut:

1. Tahap Pembersihan Data

Model yang baik harus terhindar dari data yang abnomali, yang akan mempengaruhi sebaran datanya serta garis linier dari model regresi linier. Dalam pembersihan data digunakan dengan mencari nila Znya, jika nilai Z-nya melebihi nilai $\mathrm{Z}$ pada selang kepercayaan 95\% yaitu 1,96 maka data tersebut perlu dihilangkan atau dibuang.

$\checkmark$ Tahap pembangunan model tarikan perjalanan

Dalam pembangunan model dibantu dengan menggunakan perangkat lunak statistik yaitu SPSS. Model yang digunakan adalah regresi linier berganda, dengan variabel terikat (Y) adalah jumlah perjalanan dan variabel bebas (X) adalah, luas rerata bangunan, luas total bangunan, luas parkir dan jumlah pengunjung.

$\checkmark$ Memilih variabel X yang dapat membentuk model dengan melakukan analisis korelasi $(r)$ masing-masing variabel bebas $(\mathrm{X})$ untuk melihat adanya hubungan atau tidak. Jika ada dua variabel $\mathrm{X}$ yang memiliki koefisien korelasi sama besar atau kuat, maka perlu dipilih salah satu. Sedangkan untuk hubungan antara $\mathrm{X}$ 
dan $\mathrm{Y}$, maka variabel $\mathrm{X}$ yang memiliki nilai koefisien korelasi kecil tidak akan menjadi variabel pembentuk regresi liniersehingga variabel tersebut tidak perlu dimasukkan kedalam model. Adapun cara pengujiannya sebagai berikut:

1) Nilai Korelasi dua atau lebih variabel bebas tersebut mendekati satu.

2) Nilai Korelasi parsial akan mendekati nol.

$\checkmark$ Melihat proporsi varian yang dihitung untuk regresor atau yang diterangkan variabel X, dengan melihat nilai adj $R^{2}$ atau Koefisien Determinasi Terkoreksi. Karena koefisien ini telah dikoreksi atau diperhitungkan dengan derajat bebasnya $(d f)$, sehingga dengan koefisien ini analisis regresi dapat diinterprestasikan.

$\checkmark \quad$ Validasi dan kalibrasi model dengan melakukan uji signifikansi secara individu koefisien dengan uji-t dan signifikansi menyeluruh dengan uji $F$. Uji-t dimaksudkan untuk melihat bahwa sebuah variabel $\mathrm{X}$ yang signifikan dalam keadaan hadirnya beberapa varaibel $\mathrm{X}$ yang lainnya dalam sebuah model. Dan uji $\mathrm{F}$ untuk menunjukan suatu garis regresi yang signifikan.

$\checkmark$ Selain uji koefisien dan uji kelinieran atau uji F dan uji-t serta uji kolineritas di atas, juga dilakukan pengujian autokorelasi dengan uji DW / Durbin Watson, cara pengujiannya sebagai berikut:

1) $1,65<$ DW $<2,35$ tidak terjadi autokorelasi.

2) $1,21<\mathrm{DW}<1,65$ atau $2,35<\mathrm{DW}<2,79$ tidak dapat disimpulkan.

3) $\mathrm{DW}<1,21$ atau DW $>2,79$ terjadi autokorelasi.

2. Uji Korelasi Antar Variabel

Analisis regresi mempelajari bentuk hubungan antara satu atau lebih peubah/variabel bebas (X) dengan satu peubah tak bebas (Y). dalam penelitian peubah bebas $(\mathrm{X})$ biasanya peubah yang ditentukan oleh peneliti secara bebas dalam hal ini Jumlah Kasir, Jumlah Pelayanan, dan jenis Guna Lahan., sedangkan Jumlah Bangkitan dimasukkan peubah tak bebas (Y). Sedangkan peubah tak bebas (Y) dalam penelitian berupa respon yang diukur akibat perlakuan/peubah bebas (X) 


\begin{tabular}{|c|c|c|c|c|c|c|}
\hline & & $(Y)$ & (X1) & $(\mathrm{X} 2)$ & (X3) & (X4) \\
\hline \multirow[t]{3}{*}{$(\mathrm{Y})$} & $\begin{array}{l}\text { Pearson } \\
\text { Correlation }\end{array}$ & 1 & $.709^{*}$ & $.708^{\star}$ &, 581 & ,305 \\
\hline & Sig. (2-tailed) & & 022 & 022 & ,078 & ,391 \\
\hline & $\mathrm{N}$ & 10 & 10 & 10 & 10 & 10 \\
\hline \multirow[t]{3}{*}{$(\mathrm{X} 1)$} & $\begin{array}{l}\text { Pearson } \\
\text { Correlation }\end{array}$ & $.709^{*}$ & 1 & ,347 & ,218 &,- 263 \\
\hline & Sig. (2-tailed) & ,022 & & ,325 & ,545 & ,463 \\
\hline & $\mathrm{N}$ & 10 & 10 & 10 & 10 & 10 \\
\hline \multirow[t]{3}{*}{$(\mathrm{X} 2)$} & $\begin{array}{l}\text { Pearson } \\
\text { Correlation }\end{array}$ & $.708^{*}$ & ,347 & 1 & ,577 & ,280 \\
\hline & Sig. (2-tailed) & ,022 & ,325 & & ,081 & ,434 \\
\hline & $\mathrm{N}$ & 10 & 10 & 10 & 10 & 10 \\
\hline \multirow[t]{3}{*}{ (X3) } & $\begin{array}{l}\text { Pearson } \\
\text { Correlation }\end{array}$ &, 581 & ,218 & ,577 & 1 & ,000 \\
\hline & Sig. (2-tailed) & ,078 &, 545 & ,081 & & 1,000 \\
\hline & $N$ & 10 & 10 & 10 & 10 & 10 \\
\hline \multirow[t]{3}{*}{$(\mathrm{X} 4)$} & $\begin{array}{l}\text { Pearson } \\
\text { Correlation }\end{array}$ & ,305 &,- 263 & ,280 & ,000 & 1 \\
\hline & Sig. (2-tailed) & ,391 & ,463 & ,434 & 1,000 & \\
\hline & $\mathrm{N}$ & 10 & 10 & 10 & 10 & 10 \\
\hline
\end{tabular}

\section{$\mathrm{X} 1$ = Jumlah Kasir Aktif}

$>\mathrm{X} 3=$ Jumlah Pelayanan

$>\mathrm{X} 4=$ Jenis Guna Lahan

Dari tabel dapat di lihat bahwa variabel yang di terima karena nilai lebih dari 0.5 ialah ialah X2 (0.708) dan X3 (0.581), sedangkan untuk hubungan x dan y, yang diterima ialah $\mathrm{X} 1, \mathrm{X} 2$, dan $\mathrm{X} 3$.

\begin{tabular}{|l|r|r|r|r|r|}
\hline Model & \multicolumn{1}{|l|}{ R } & R Square & R Square & of the & Watson \\
\hline 3 & $.963^{\mathrm{c}}$ &, 928 &, 891 & 4,426 & 2,291 \\
\hline
\end{tabular}

c. Predictors: (Constant), (X1), (X4), (X3)

d. Dependent Variable: $(\mathrm{Y})$

Anova

\begin{tabular}{|c|c|c|c|c|c|c|}
\hline Model & & $\begin{array}{l}\text { Sum of } \\
\text { Squares }\end{array}$ & df & $\begin{array}{c}\text { Mean } \\
\text { Square }\end{array}$ & $\mathrm{F}$ & Sig. \\
\hline \multirow[t]{3}{*}{1} & Regression & 816,171 & 1 & 816,171 & 8,087 & $.022^{\mathrm{a}}$ \\
\hline & Residual & 807,429 & 8 & 100,929 & & \\
\hline & Total & 1623,600 & 9 & & & \\
\hline \multirow[t]{2}{*}{2} & Regression & 1238,170 & 2 & 619,085 & 11,244 & $.007^{b}$ \\
\hline & Residual & 385,430 & 7 & 55,061 & & \\
\hline \multirow{4}{*}{3} & & & & & & \\
\hline & Regression & 1506,080 & 3 & 502,021 & 25,631 & $.001^{\circ}$ \\
\hline & Residual & 117,520 & 6 & 19,587 & & \\
\hline & Total & 1623,600 & 9 & & & \\
\hline
\end{tabular}

a. Predictors: (Constant), (X1)

b. Predictors: (Constant), (X1), (X4)

c. Predictors: (Constant), (X1), (X4), (X3)

d. Dependent Variable: $(Y)$ 
Dengan cara yang sama dengan uji t, maka kita dapat melihat dari nilai sig. Karena nilai $\mathrm{F}$ hitung sebesar 25.631 yang memiliki tingkat sig 0,001 yang lebih kecil dari 5\% (bisa pula 10\%, gunakan yang paling dekat apabila nilai sig sebesar 0,07 maka signifikan pada tingkat $10 \%$ ) maka kita dapat simpulkan bahwa semua variabel bebas secara bersama-sama berpengaruh signifikan terhadap variabel terikat dan hipotesisnya diterima

Dari hasil model uji, Variebel 3 lebih bisa diterima karena nilai signifikannya paling kecil di bawah 0.05 .

Dari hasil model uji, Variebel 3 lebih bisa diterima karena nilai signifikannya paling kecil di bawah 0.05 .

\section{KOEFISIEN}

$y=3,686+20,86 X 1+9,657 X 4+10,627 X 3$

\begin{tabular}{|c|c|c|c|c|c|c|c|c|}
\hline \multirow[b]{2}{*}{ Model } & & \multicolumn{2}{|c|}{$\begin{array}{l}\text { Unstandardized } \\
\text { Coefficients }\end{array}$} & \multirow{2}{*}{\begin{tabular}{|c|}
$\begin{array}{c}\text { Standardiz } \\
\text { ed } \\
\text { Coefficient } \\
\text { s }\end{array}$ \\
Beta \\
\end{tabular}} & \multirow[b]{2}{*}{$\mathrm{t}$} & \multirow[b]{2}{*}{ Sig. } & \multicolumn{2}{|c|}{ Collinearity Statistics } \\
\hline & & $\mathrm{B}$ & Std. Error & & & & Tolerance & VIF \\
\hline \multirow[t]{2}{*}{1} & (Constant) & 36,571 & 9,556 & & 3,827 &, 005 & & \\
\hline & $(\mathrm{X} 1)$ & 19,714 & 6,933 &, 709 & 2,844 &, 022 & 1,000 & 1,000 \\
\hline \multirow[t]{3}{*}{2} & (Constant) & 15,302 & 10,433 & & 1,467 & ,186 & & \\
\hline & $(X 1)$ & 23,581 & 5,308 & ,848 & 4,443 &, 003 & ,931 & 1,074 \\
\hline & $(x 4)$ & 10,151 & 3,667 & 528 & 2,768 & 028 & 931 & 1,074 \\
\hline \multirow[t]{4}{*}{3} & (Constant) & 3,686 & 6,970 & &, 529 & $\overline{7616}$ & & \\
\hline & $(\mathrm{X} 1)$ & 20,863 & 3,250 &, 750 & 6,420 &, 001 & ,883 & 1,132 \\
\hline & $(\mathrm{X} 4)$ & 9,657 & 2,191 &, 503 & 4,407 &, 005 & ,927 & 1,078 \\
\hline & $(\mathrm{X} 3)$ & 10,627 & 2,874 & ,417 & 3,698 & ,010 & 949 & 1,054 \\
\hline
\end{tabular}

Untuk melihat apakah suatu variabel bebas memiliki pengaruh yang signifikan atau tidak dapat dilihat dari nilai t atau dari signifikansinya. Apabila suatu variabel terikat memiliki sig lebih kecil dari pada 0,1 atau $10 \%$ maka dapat dikatakan bahwa variabel bebas tersebut signifikan pada tingkat $10 \%$, bila lebih kecil dari 0,05 atau 5\% maka dapat dikatakan bahwa variabel bebas tersebut signifikan pada tingkat 5\%, jika memiliki sig yang lebih kecil dari 0,01 tau 1\% maka dapat dikatakan bahwa variabel tersebut signifikan pada tingkat 1\%. Apabila dinyatakan signifikan maka hipotesis yang telah kita rumuskan dapat diterima. (Yang Umum digunakan 5\%)

Berdasarkan hal tersebut maka hipotesis 1 hingga hipotesis 3 dapat diterima, dan disimpulkan bahwa terdapat pengaruh positif yang signifikan dari x1, x2 dan x3 terhadap y. 


\section{Dependent Variable: (Y)}

\section{Collinearity Diagnostics}

\begin{tabular}{|c|c|c|c|c|c|c|c|}
\hline \multirow[b]{2}{*}{ Model } & \multirow[b]{2}{*}{ Dimension } & \multirow[b]{2}{*}{$\begin{array}{c}\text { Eigenvalu } \\
\mathrm{e}\end{array}$} & \multirow[b]{2}{*}{$\begin{array}{l}\text { Condition } \\
\text { Index }\end{array}$} & \multicolumn{4}{|c|}{ Variance Proportions } \\
\hline & & & & (Constant) & $(\mathrm{X} 1)$ & $(X 4)$ & $(\mathrm{X} 3)$ \\
\hline \multirow[t]{2}{*}{1} & 1 & 1,943 & 1,000 & ,03 &, 03 & & \\
\hline & 2 & ,057 & 5,845 & ,97 & ,97 & & \\
\hline \multirow[t]{3}{*}{2} & 1 & 2,804 & 1,000 & ,01 & ,01 & ,02 & \\
\hline & 2 &, 163 & 4,145 &, 00 & ,28 & ,46 & \\
\hline & 3 &, 033 & 9,222 & 99 & 71 &, 52 & \\
\hline \multirow[t]{4}{*}{3} & 1 & 3,725 & 1,000 & ,00 & ,01 & ,01 & ,01 \\
\hline & 2 & , 169 & 4,699 & ,00 & ,18 &, 51 & ,02 \\
\hline & 3 &, 077 & 6,963 &, 00 & ,39 & ,06 & ,81 \\
\hline & 4 & ,030 & 11,209 & ,99 & ,42 & ,42 &, 16 \\
\hline
\end{tabular}

Model Regresi perjalanan didapatkan sebagai berikut. Dari output SPSS dengan metode enter dengan memasukkan variabel-variabel yang korelasinya kuat dengan jumlah perjalanan yaitu variabel Jenis Pelayanan, sehingga didapatkan

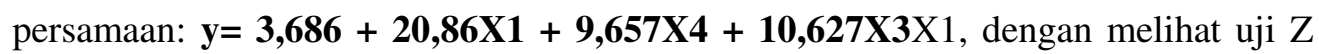
untuk $X 1$ adalah $Z_{X 1}=63,562$ atau nilai sig $<0,05$, artinya model ini dapat diterima atau dapat mewakili untuk seluruh zona dengan tingkat kepercayaan $95 \%$.

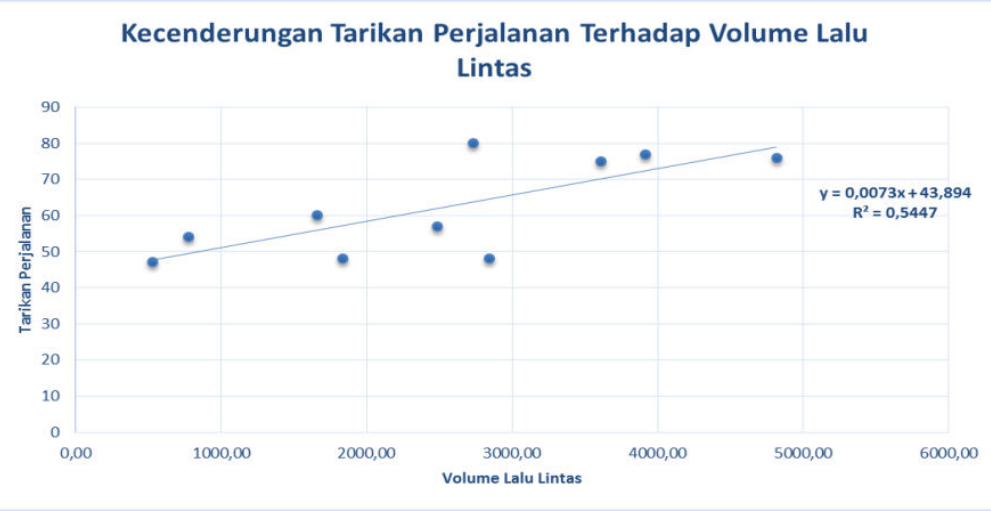

\begin{tabular}{|c|c|c|c|c|c|c|c|c|c|c|c|c|}
\hline \multirow[b]{2}{*}{ No } & \multirow[b]{2}{*}{ Minimarket } & \multirow[b]{2}{*}{ Lokasi } & & \multirow{2}{*}{$\begin{array}{c}\text { Volume } \\
\text { (smp/jam) }\end{array}$} & \multicolumn{7}{|c|}{ Tarikan Perjalanan } & \multirow{2}{*}{\begin{tabular}{|c|}
$\begin{array}{l}\text { Proporsi Pengunjnung } \\
\text { terhadap volume lalin }\end{array}$ \\
$(\%)$ \\
\end{tabular}} \\
\hline & & & & & \begin{tabular}{|l|} 
jalan Ka \\
(Orang) \\
\end{tabular} & \multicolumn{2}{|c|}{ Sepeda Motor } & \multicolumn{2}{|c|}{ Mobil Pribadi } & \begin{tabular}{|l|} 
Jumlah \\
(Kend) \\
\end{tabular} & $\begin{array}{c}\text { Jumlah } \\
\text { (Orang) }\end{array}$ & \\
\hline 1 & Indomart & Dekat Perumahan GMM & Propinsi & 2486,30 & 7 & 33 & 39 & 6 & 10 & 39 & 57 & 2,3 \\
\hline & & & & & & & & & & & & \\
\hline 3 & Indomart & Dekat Persimpangan Kalimalang & Propinsi & 1657,40 & 8 & 37 & 44 & 4 & 8 & 41 & 60 & 3,6 \\
\hline 5 & Alfamart & Dekat Persimpangan Cibitung & Nasional & 3911,90 & 10 & 46 & 55 & 7 & 12 & 53 & 77 & 2,0 \\
\hline 6 & Alfamart & Dekat Persimpangan Kampung Utan & Nasional & 2846,20 & 15 & 20 & 25 & 5 & 9 & 25 & 48 & 1,7 \\
\hline 7 & Alfamart & Dekat Akses Tol Cikarang Barat & Kabupaten & 4815,50 & 13 & 40 & 48 & 8 & 15 & 48 & 76 & 1,6 \\
\hline 8 & Indomart & Dekat Persimpangan Lippo Cikarang & Kabupaten & 2733,40 & 8 & 44 & 53 & 11 & 19 & 55 & 80 & 2,9 \\
\hline & & RATA-RATA & & 2520,41 & & & & & & & & 3,46 \\
\hline
\end{tabular}




\section{KESIMPULAN}

1 Survai pengamatan lapangan dibutuhkan untuk memilih lokasi yang sesuai dengan hasil keluaran penelitian, karena tidak semua lokasi minimarket dapat dijadikan sebagai objek penelitian. Objek penelitian yang dibutuhkan dalam penelitian ini memiliki kriteria antara lain :

Disesuaikan dengan status jalan yang ada di Kabupaten Bekasi antara lain:

a Jalan Nasional adalah ruas jalan Jalan Teuku Umar;

b Jalan Propinsi adalah Jalan Raya Setu; Jalan Kalimalang;

c Jalan Kabupaten adalah Jalan Raya Cikarang Cibarusah;

Dengan karakteristik indikator
a. Karakteristik luasan;
b. Karakteristik pelayanan;
c. Karakteristik tata guna lahan;

2 Bangkitan perjalanan untuk Minimarket memiliki hubunngan terhadap Jumlah kasir aktif; Jumlah pelayanan dan Jenis guna lahan.

3 Persamaan hubungan yang terbentuk adalah $\mathrm{Y}=3,686+20,86 \mathrm{X} 1+9,657 \mathrm{X} 4+$ $10,627 \times 3$.

4 Kondisi jalan yang diwakili oleh volume lalu lintas per status jalan perpengaruh langsung terhadap tarikan perjalanan.

5 Bahwa proporsi kunjungan Minimarket terhadap volume lalu lintas adalah 3,46 $\%$

6 Dari grafik kecenderungan (Trend) bahwa jumlah pengunjung (tarikan perjalanan) akan meningkat seiring lokasi Minimarket terletak di status jalan dan peningkatan volume lalu lintas.

\section{SARAN}

1. Perlu ada penelitian lanjutan untuk melihat tarikan perjalanan Minimarket dari aspek-aspek yang lain yang terkait.

2. Untuk pengembangan penelitian selanjutnya, disarankan agar peneliti berikutnya dapat menambah variabel dan disesuaikan dengan variable jenis Minimarket.

3. Disarankan untuk menambah jenis sample di perbanyak untuk tiap tiap Janis supermarket/ kelas jalan 


\section{DAFTAR PUSTAKA}

1. Anonim, Undang Undang Nomor 22 Tahun 2009 Tentang Lalulintas dan Angkutan Jalan, 2009, Jakarta.

2. Sugiyono, (2007), "Statistik Untuk Penelitian", Edisi kedua belas, Alfabeta, Bandung.

3. Tom V. Mathew dan K V Krishna Rao, 2006, "Introduction to Transportation Engineering",

4. Direktorat Jenderal Bina Marga Departemen Pekerjaan Umum, Manual Kapasitas Jalan Indonesia, 1997, Jakarta.

5. Wright, Paul H., Ashford, Norman J., Transportation Engineering : Planning and Design, Third Edition, 1989, John Wiley and Sons Inc., Canada

6. David A Hensher, Kenneth J Button. (2000). Handbook of Transport Modelling, Elsevier Science Ltd. United Kingdom.

7. F D Hobbs. (1979). Traffic Planning And Engineering, second edition, Pergamon Press, England.

8. Ortuzar J D, and Wilumsen L G.(1994). Modelling Transport, second edition, John Wiley \& Sons, Chichester, England.

9. Spyros et al. (1983). Metode dan Aplikasi Peramalan, Edisi Kedua diterjemahkan oleh Untung S Andriyanto dan Abdul Basith, Penerbit Erlangga, Jakarta.

10. Hadi S. (2004). Metodologi Research : Jilid 2, Edisi 2, Penerbit ANDI, Yogyakarta.

11. Harinaldi. (2005). Prinsi-Prinsip Statistik Untuk Teknik dan Sains. Penerbit Erlangga, Jakarta.

12. Ronald E Walpole, Raymond H Myers. (1995). Ilmu Peluang dan Statistika untuk Insinyur dan Ilmuan, Edisi Keempat, terjemahan RK. 